Bangladesh J. Zool. 40(1): 101-108, 2012

\title{
PESTICIDE RESIDUES AND HARMFUL ORGANIC POLLUTANTS IN SOME FRESHWATER FISHES FROM MATLAB FLOODPLAIN AREA, BANGLADESH
}

\author{
Maria Zaman, M. Niamul Naser ${ }^{1}$, Mozaffar Hossain, Moazzem Husain, \\ Aminul Islam, Kazi Azizul Islam and Nasim Sultana \\ Analytical Research Division, Bangladesh Council of Scientific \& Industrial \\ Research (BCSIR), Dhanmondi, Dhaka-1205, Bangladesh
}

\begin{abstract}
The level of organochlorine pesticide residues (OCPs), viz. $\alpha-, \beta-, \gamma$-BHC, heptachlor, aldrin, heptachlor epoxide isomer B, dieldrin, 4,4'-DDE, endrin, 2,4DDD, 4,4'-DDT, 4,4'-DDD, 2,4'-DDT in fish samples from Matlab floodplain areas were determined. The fish samples were extracted with ethyl acetate, the extracts were cleaned up by sulphuric acid treatment and analyzed by gas chromatograph (GC) fitted with electron captured detector and gas chromatograph-mass spectrometer (GC-MS). The result showed that none of the studied fishes contained organochlorine pesticide residues but consist some other harmful organic contaminants in tissues.
\end{abstract}

Key words: Organochlorine pesticide residue, organic pollutants, fish, floodplain area.

\section{INTRODUCTION}

Bangladesh is an agricultural country where more than $80 \%$ of the people depend on agriculture for their living. With the growing demand for food, use of chemicals like fertilizer and pesticides in agricultural land has increased since 1954. Constant use of pesticides in crop fields has led to decreased biodiversity of fauna. Pesticides in aquatic ecosystem have become a matter of concern because of their toxicity and tendency to accumulate in food chain. Fishes live in the aquatic column; they are facing challenge for surviving from pollutants, particularly from various chemical fertilizers and pesticides used in or adjacent paddy fields or flood lands. Pesticides reach aquatic ecosystems by direct application, spray drift, aerial spraying, erosion and run off from agriculture land. These huge amount of pesticides may get deposited in the flood lands and other open water wetlands and rivers of the country (Plimer 1988, Miskiewicz and Gibbs 1994). Availability of very limited data (Das et al. 2002) indicates that not much has been done in this regards here in Bangladesh. Moreover, there has been no elaborate study on Organochlorine pesticide (OCPs) residues in fishes from Bangladesh except Nahar et al. (2008).

Some common floodplain fishes were selected by their feeding habit (Shafi and Quddus 1982) and their availability. Fishes: Boal (Wallago attu), Rui (Labeo rohita), Koi (Anabas testudineus), Khalisha (Colisa fasciatus), Puti (Puntus chola) and Kachki (Corica soborna) were selected which were common in Matlab

${ }^{1}$ Corresponding author: Department of Zoology, University of Dhaka, Dhaka-1000, Bangladesh. E-mail: mnnaser@du.ac.bd 
floodplain. The present work was carried out to determine some organochlorine pesticide residues and other harmful organic pollutants in the selected common floodplain fishes of Matlab, Chandpur. Further, the potential health risks posed to consumers from the exposure to these compounds through the ingestion of these fishes grown in these areas have been discussed.

\section{MATERIAL AND METHODS}

A survey was conducted on the floodplain areas of Matlab, Chandpur District (Fig. 1) located on the bank of Meghna River, Bangladesh. Fish samples were collected from four sampling sites of the Meghna-Dhonagoda floodplain project area which included a pond, a crop field, a canal and Meghna River, where the following fishes were sampled: carnivores- Boal (Wallagonia attu) and Koi (Anabas testudineus); herbivore- Rui (Labeo rohita) and Kachki (Corica soborna); omnivore- Khalisha (Colisa fasciatus) and Puti (Puntius chola).
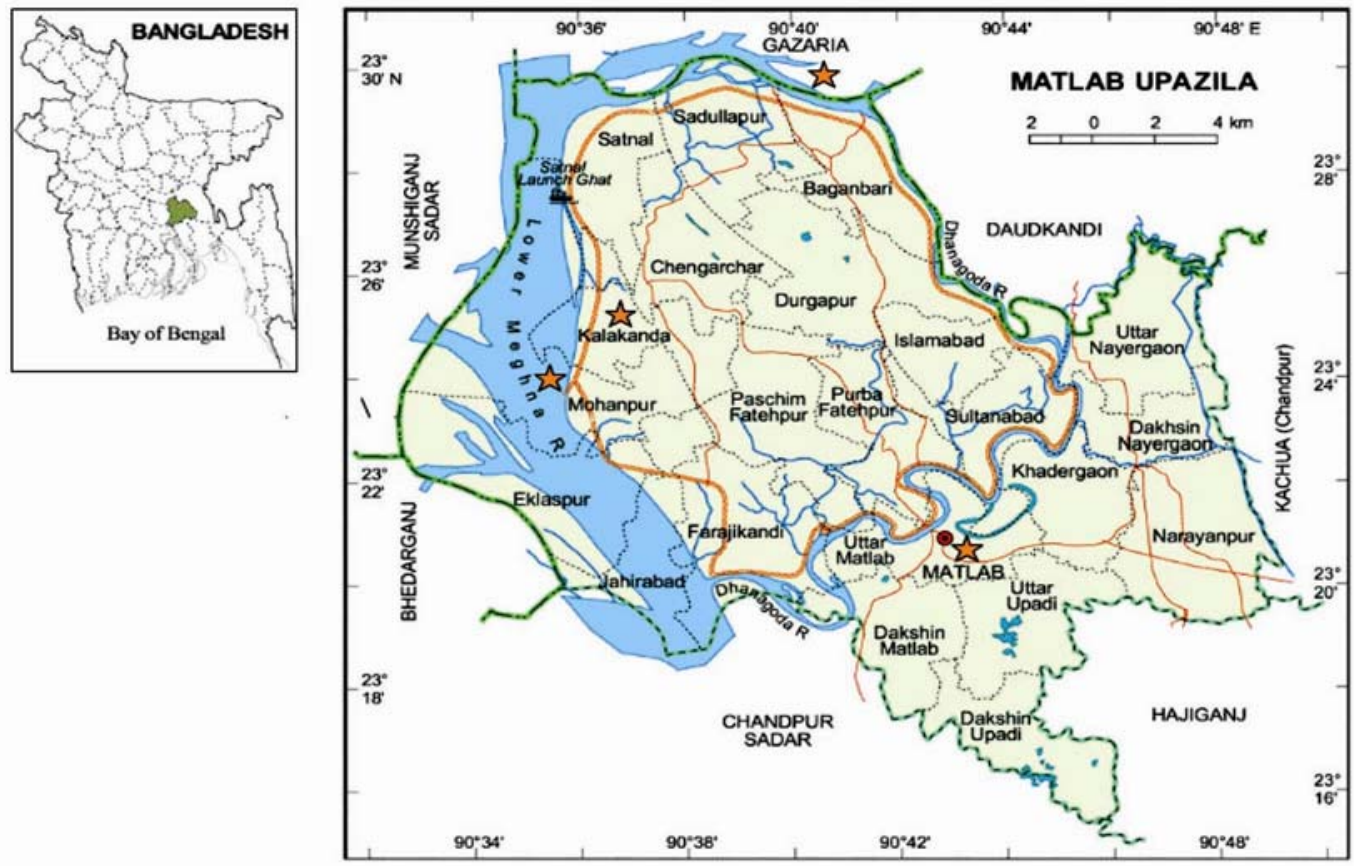

Fig. 1. Map showing the location of the study areas at Matlab, Chandpur in Bangladesh. Study sites are: Meghna-Dhonagoda project area, a pond (Kalakanda), a crop field (Gazaria), a canal (Kalakanda) and Meghna River.

The fishes were collected by gears and traps. Rui fish were collected from a culture pond, Koi and Khalisha from a crop field, Puti and Kachki from a canal and Boal from Megna river. Each fish was measured $(\mathrm{cm})$ and had been stored in a refrigerator in the laboratory until they were studied. 
Ethylacetate, cyclohexane (Merck Germany) were used pesticide residue grade, Sulphiuric acid (BDH, England), anhydrous sodium sulphate (Merck, Germany) were GR grade. Sea sand (GR, India) washed by ethyl acetate for 3 times before use. A mixture of 13 chlorinated pesticides standard was obtained from Sigma-Aldrich.

Extraction of fish samples was carried out according to EMP manual (Akerblom 1995). About $100 \mathrm{~g}$ of fish sample was taken from deep freeze and put to laboratory temperature until thawing. Each sample was chopped into small pieces and mixed thoroughly. Ten grams of sample were ground in a mortar with $10 \mathrm{~g}$ sand and $30 \mathrm{~g}$ sodium sulphate and more sodium sulphate was added to make the sample float freely. The ground sample was taken in a quick-fit conical flask. Then it was extracted with $50 \mathrm{ml}$ ethyl acetate by shaking for three minutes. This extraction was repeated three times with $20 \mathrm{~mL}$ ethyl acetate. The extract was combined and then filtered through the glass wool. The filtrate was evaporated to two $\mathrm{ml}$ by rotary vacuum evaporator at temperature not exceeding $40^{\circ} \mathrm{C}$. The solvent was exchanged from ethyl acetate to cyclohexane by evaporation and the volume of the solution was readjusted to two $\mathrm{ml}$.

Acid solution was prepared by mixing cyclohexane and concentrated sulphuric acid. The two chemicals were mixed in a column at $1: 4$ ratios, upper organic part was withdrawn and discarded. The two $\mathrm{ml}$ extract and one $\mathrm{ml}$ acid solution was taken into a fresh screw cap test tube and was inverted 20 times (about 40 second). Then the mixed solvent was centrifuged for three minutes to separate two layers. The upper organic layer was taken into a fresh vial and used for pesticide residue analysis by GC and GC-MS.

The gas chromatograph GC-14B (Shimadzu) equipped with ECD (Electron Captured Detector) mode and having fused silica capillary column (SPB-5) was used for analysis. The column was of $60 \mathrm{~m}$ length and $0.25 \mathrm{~mm}$ internal diameter (ID). Column oven initial and final temperature was $80^{\circ} \mathrm{C}$ and $300^{\circ} \mathrm{C}$ respectively, carrier gas-helium (purity-99.997\%), gas flow $1.5 \mathrm{ml} / \mathrm{min}$, column pressure 100 (kilo pascal), injection volume $0.4 \mu 1$, injection temperature $280^{\circ} \mathrm{C}$ and interface temperature $300^{\circ} \mathrm{C}$.

The gas chromatograph mass spectrometer GC-17A \& GCMS-QP5050A (Shimadzu Japan) equipped with electron ionization (EI) mass detector and $30 \mathrm{~m}$ length $\& 0.252 \mathrm{~mm}$ internal diameter (ID) fused silica capillary column (DB-1) was used for mass analysis under the following analytical conditions; temperature ranged from $150^{\circ} \mathrm{C}$ to $250^{\circ} \mathrm{C}$, speed $3^{\circ} \mathrm{C} / \mathrm{min}$, carrier gas-helium (purity-99.998\%), gas flow $50 \mathrm{~mL} / \mathrm{min}$., column pressure 100 (kilo pascal), injection volume $0.4 \mu \mathrm{l}$, injection temperature $230^{\circ} \mathrm{C}$ and interface temperature 
$250^{\circ} \mathrm{C}$. The recovery of organochlorine ranged within $75-90 \%$. Chromotogram standard is given in Fig. 2.

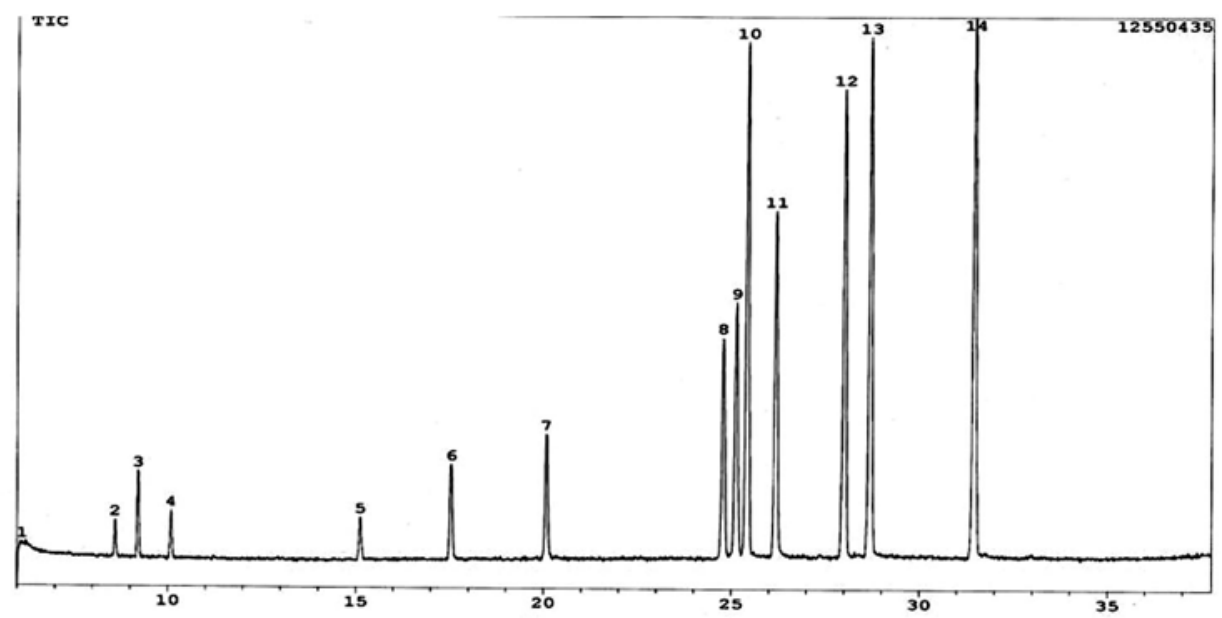

Fig. 2. Chromotogram of mixed standard 2, $\alpha$-BHC, 3. $\gamma$-BHC, 4. $\beta$-BHC, 5. Heptachlor, 6. Aldrin, 7 , heptachloro epoxide isomer B, 8. dieldrin, 9. 4,4'-DDE, 10. endrin, 11. 2,4-DDD, 12. 4,4'DDT, 13. 4,4'-DDD, 14.2,4'-DDT

\section{RESULTS AND DISCUSSION}

Fish samples were analyzed by GC and GC-MS for the identification of organochlorine pesticide residue, but none of them was found to contain detectable organochlorine pesticide residue (Table 1, Fig. 3).

Boal and Koi fish contained harmful and toxic compounds (Table 1 and Figure $3 \mathrm{a}$ and 3c). In Boal 2-Amino-4-hydroxytoluene, Dichlorotetrahydro furan, Di-n-octylphalate were detected which are carcinogenic to human and widely used in different industries. Butylated hydroxytoluene, Phenol 2,6-bis(1,1dimethylethyl)-4-(1-methyl-1-phenylethyl), 2-Toluic hydrazide, 2-butyltetrahydro furan were found in Koi. All these compound are highly toxic and industrial effluent. Trichlorobenzoic acid found in Boal fish was a post-emergence herbicide used in conjunction with other growth regulator herbicides in cereal, and grass seed crops to control broad leaved annual and perennial weeds (Tomlin 1994), but it is not registered for use as an herbicide because of its toxicity (PAN 2006). Compounds found in these fishes might be due to highly carnivore feeding habit.

Between two herbivore, Rui fish sample showed no chemical compounds in its muscle tissues (Figure $3 \mathrm{~b}$ and Table 1). This fish was collected from a culture pond and the cultured species had no organic pollutants in their muscle or the 
chemicals present at very low concentrations or below the limit of detection. On the other hands Kachki contain p-chloroamphetamine, 2,5-Furandione,3methyl, N,N'-Bis(2-naphthyl) terephthalamide, Phenol 2,6-bis(1,1dimethylethyl)-4-(1-methyl-1-phenylethyl) and 2-(Benzylthio)-4-(4 chlorophenyl)6-(p-tolyl)nicotinonitrile, all are industrial pollutants, neuro toxic and very harmful to human (Lewis et al. 2002). The Kachki fishes are herbivore in nature. Though they only consumed herbs, phyto and zooplankton in their feeding habit, but some organic pollutants (Table 1. Fig. 3f) were found from their muscle which are very harmful in nature.
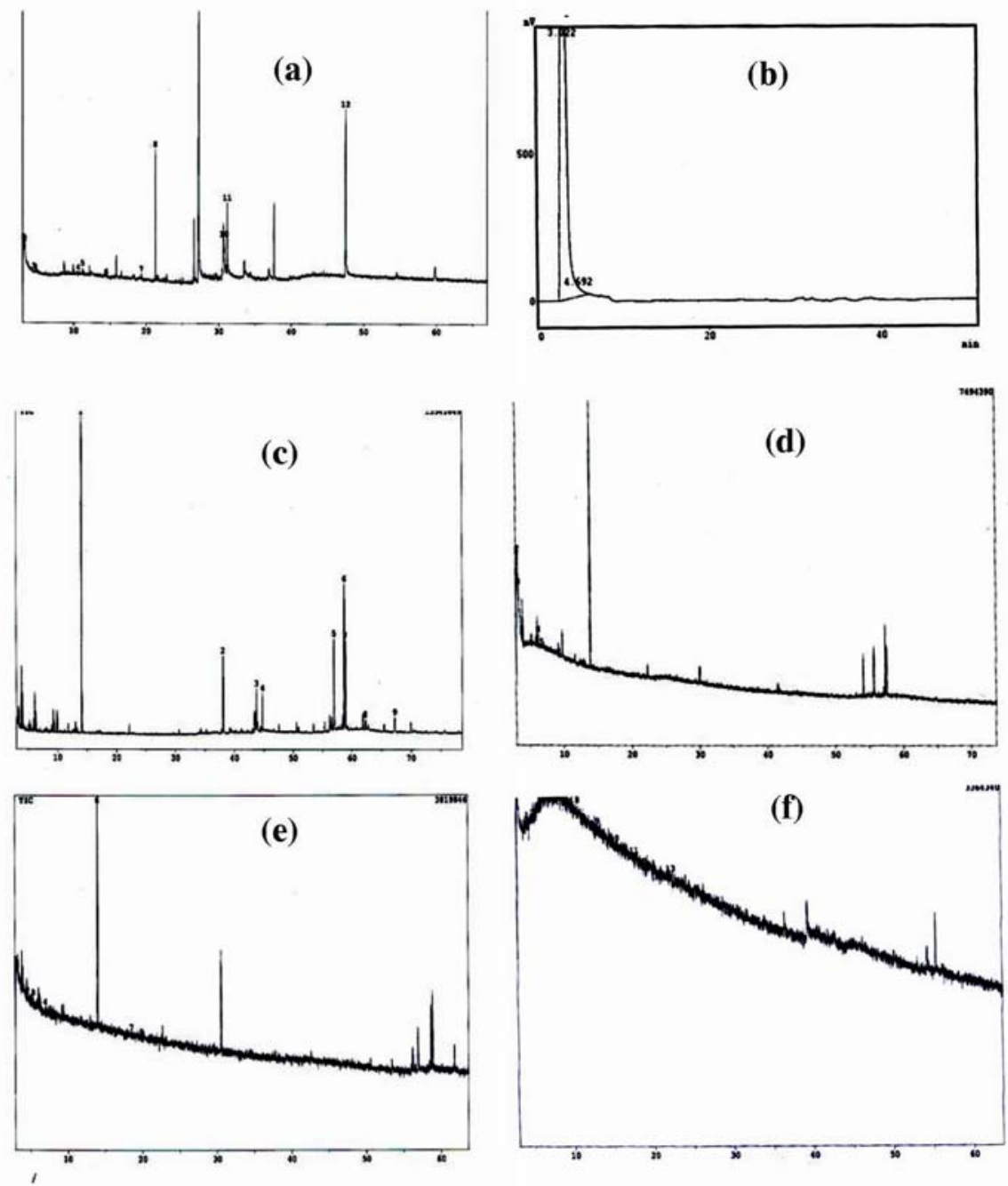

Fig. 3. GCMS \& GC Chromatograms of a. Boal (Wallagonia attu), b.Rui (Labeo rohita), c. Koi (Anabas testudineus), d. Khalisha (Colisa fasciatus) e. Puti (Puntius chola) \& f. Kachki (Corica soborna). 
Between two omnivore species, Khalisha and Puti (Figure 3d \& 3e) contained, organic pollutants in their muscles. Phenolic compounds, such as Benzophene, 5-chloro-2-[[N-[diacetyloxy] acetyl] methylamino, Dibutyltin dibromide, 4, 4'-(5-Iodofurfurylidene) bis (antipyrine) were found in these species. These compounds could be obtained by these fishes for their feeding habit (Shafi and Quddus 1982).

Table 1. Organic pollutants found in Fishes: Boal (Wallago attu), Rui* (Labeo rohita), Koi (Anabas testudineus), Khalisha (Colisa fasciatus) Puti (Puntius chola) and Kachki (Corica soborna).

\begin{tabular}{|c|c|c|}
\hline Name of Organic Compounds & $\begin{array}{l}\text { Type of } \\
\text { pollutant }\end{array}$ & Fishes \\
\hline Trichlorobenzoic acid & Insecticide & Boal, Koi, Khalisha \\
\hline Benzaldehyde,4-hydroxy & Ind. pollutant & Boal \\
\hline 1,2-Benzisothiazole & Ind. pollutant & Boal, Khalisha \\
\hline Dibutyl phthalate & Plasticizer & Boal \\
\hline 2 Amino-4-hydroxytoluene & Ind. pollutant & Boal \\
\hline Dichlorotetrahydro furan & Ind. pollutant & Boal \\
\hline Di-n-octylphalate & Plasticizer & Boal,Puti \\
\hline $\begin{array}{l}\text { N-(4-chloro-2-(2-chlorobenzoyl)phenyl)-4- } \\
\text { (diethylamino sulfonyl) benzamide }\end{array}$ & Ind. pollutant & $\begin{array}{l}\text { Boal, Khalisha, } \\
\text { Kachki }\end{array}$ \\
\hline Acetamide 2,2,2-trichloro-N-(3-methyl phenyl) & Ind. pollutant & Boal,Puti \\
\hline p-Chloroamphetamine & Insect repellent & Boal, Kachki, \\
\hline Butylated Hydroxytoluene & Ind. pollutant & Koi \\
\hline $\begin{array}{l}\text { Phenol 2,6-bis(1,1-dimethylethyl)-4-(1-methyl-1- } \\
\text { phenylethyl) }\end{array}$ & Ind. pollutant & Koi,Khalisha,Kachki \\
\hline 2-Toluic hydrazide & Ind. pollutant & Boal, Koi, Khalisha \\
\hline 2-butyltetrahydro furan & Ind. pollutant & Koi \\
\hline 2,4-Bis(dimethylbenzyl-6-t-butylphenol) & Ind. pollutant & Koi, Khalisha, Kachki \\
\hline $\begin{array}{l}\text { 9-Phenanthrenemethanol,1,3-dichoro-.alpha.-[2- } \\
\text { (dibutylamino) ethyl]-6-[trifluromethyl] }\end{array}$ & Ind. pollutant & Koi, Khalisha \\
\hline Carbonochloridic acid, 2-methylpropyl ester & Ind. pollutant & Khalisha \\
\hline Dichloroacetamide & Ind. pollutant & Puti, Kachki, Khalisha \\
\hline $\begin{array}{l}\text { Benzophene,5-chloro-2-[[N-[diacetyloxy]acetyl] } \\
\text { methylamino] }\end{array}$ & Ind. pollutant & Khalisha \\
\hline Dibutyltin dibromide & Ind. pollutant & Puti \\
\hline 4,4'-(5-Iodofurfurylidene) bis (antipyrine) & Ind. pollutant & Puti \\
\hline 1-phenanthrenecarboselenoic acid & Ind. pollutant & Puti , Koi \\
\hline 2,5-Furandione,3-methyl & Ind. pollutant & Puti, Kachki. \\
\hline N,N'-Bis(2-naphthyl) terephthalamide & Ind. pollutant & Kachki \\
\hline $\begin{array}{l}\text { 2-(Benzylthio)- } 4-(4 \text { chlorophenyl)- } 6-(\mathrm{p}- \\
\text { tolyl)nicotinonitrile }\end{array}$ & Ind. pollutant & Kachki \\
\hline
\end{tabular}

*Not detectable any organic pollutants; Ind. Pollutant-Industrial Pollutant. 
However, the tested fish samples contained organic pollutants (Table 1) which are very harmful and carcinogenic to human. Most of these compounds are hazardous and used for making insecticides, discharged from industrial effluent, plasticizer, pharmaceuticals, dyes, chemicals, explosives, disinfectants etc. and many of them are no longer officially registered for use because of their toxicity. These substances are considered special hazardous because of their particular toxicity, tumorigenicity, mutagenicity, reproductive toxicity, flammability, explosivity, corrosivity or reactivity which pose a special hazard to health and safety (The Pennsylvania Code 2011).

Concluding remarks: From the above discussion it is quite evident that no persistent organic pollutants (POPs) or chlorinated pesticides were detected, but some major organic pollutants were detected from the fish samples. Meghna river and its tributaries support vast potential fishery resources. This area fulfills the major protein demand of the country. None of the fishes studied contained organochlorine pesticide residues, but indicated some degree of industrial pollutants and contamination in the fishes of the sampling sites. Organic contaminants, Industrial effluent, accidental spills, pollutants, natural organic substances, insecticides, herbicides and agricultural chemicals were found in fish tissues which clearly indicated the contamination of the water of Matlab floodplain and adjacent areas. It could become a serious threat to our ecosystem, water resources, fish population, and human health. This study was area - specific giving a holistic picture of the floodplains of Bangladesh. The extensive work is required to determine the overall picture of the pollutants which could be present in the fishes and environment of Bangladesh.

\section{LITERATURE CITED}

AKERBLOM, M. 1995. Environmental Monitoring of Pesticide Residue. Gudelines for the SADC Region. Swedish University of Agricultural Science. Upsala. Sweden, pp 1-130.

DAS, B., KHAN, Y.S., DAS, P., SHAHEEN, S.M. 2002 Organochlorine pesticide residue in catfish, Tachysurus thalassinus (Ruppell, 1835), from the South Patches of the Bay of Bangal. Environ Pollut. 120: 255-259.

LEWIS, R.J., WILY S.J. and HOWLEY. 2002. Condensed Chemical Dictionary, $13^{\text {th }}$ ed., John Willey and Sons, NY, Chicago, USA.

MISKIEWICZ, A.G. and GIBBS, P.J. 1994. Organochlorine pesticides and hexachorobenzene in tissues of fish and invertebrates caught near a sewage outfall. Environmental Poll. 84: 269-277.

NAHAR, N., MAMUN, M.I.R., ZAMIR, R. and ZAMAN, M.M. 2008. Analysis of pesticide residues in some local fish and vegetables. Dhaka Univ. J. Sci. 56(2): 179-182.

PAN. 2006. 2,3,6-trichlorobenzoic acid. Pesticide Action Network: Pesticide Database. Avaiable at: http://www.pesticideinfo.org/Detail_Chemical.jsp?Rec_Id=PC34527

PLIMER, J.R. 1988. Movement of pesticide from the site of application, IAEA SM-297/35, in Pesticide, Food and Envirnomental Implications 61-77. 
SHAFI, M. and QUDDUS, M.M.A. 1982. Bangladesher Matsho Sampad (in Bengali). 1st ed. Bangla Academy, Dhaka, pp.1-426.

THE PENNSYlVANIA CODE. 2011. Hazardous Substance List, Chapter 323. www.pacode.com/ secure/data/034/ chapter323/chap323toc.html

TOMLIN, R. 1994. The pesticide manual, 10 th ed. British Crop Protection Council and The Royal Society of Chemistry, Crop Protection Publications, The Bath Press, Bath.

(Manuscript received on December 20, 2011; revised on May 15, 2012) 